\title{
CHOSEN ASPECTS OF IT SYSTEMS IN MANAGEMENT AND ACCOUNTING IN COMPANIES UNDER GLOBALIZATION
}

\author{
Karolina Rybicka ${ }^{1, a,{ }^{*}}$ and Piotr Rybicki ${ }^{2, b}$ \\ ${ }^{1}$ Czestochowa University of Technology, ul. Armii Krajowej 19 B, 42-200 Czestochowa, Poland \\ ${ }^{2}$ Czestochowa University of Technology, ul. Armii Krajowej 19 B, 42-200 Czestochowa, Poland \\ akarolina.rybicka@wz.pcz.pl, ${ }^{b}$ rybickipiotr @wp.pl \\ *Corresponding author
}

Cite as: Rybicka, K., Rybicki, P. (2018). Chosen aspects of it systems in management and accounting in companies under globalization, Ekonomicko-manazerske spektrum, 12(2), 57-66.

Available at: dx.doi.org/10.26552/ems.2018.2.57-66

\begin{abstract}
The functioning of enterprises undergoes continuous processes along with changes taking place in the environment. Such processes, like the globalization of economy, taking into consideration the issues of CSR, competitiveness and development of information technologies are increasingly affecting business units. Electronic media are present in almost all societies. New technologies have contributed significantly to the so-called new quality in enterprise's management. Continuous and dynamic digital changes lead to the transformation of mutual relations between companies. It can be said that this is the new stage in the globalization process. Such dynamic development of information and communication technologies (ICT), noticeable in the last few years, has significantly influenced the functioning of modern organizations operating in the global economy. The usage of new social media has increased in the last few years, with most of the population. The importance of such technology-enabled networks, as well as of the data they can generate, is obvious also at the financial level, with the entrance of social media owners in the share market. Empirical research of both social media and Big Data for management is rather still at the beginning stage. However, it is observed that new technologies have already changed management system in companies. Companies require now fast and accurate information. The relevant information is essential for efficient and effective management of companies. The aim of the paper is to present the role of the information and IT system in the enterprise's management. There are presented the most important ideas of the information system. Integrated IT systems and their impact on the running business organisation in the global market are also presented in the paper.
\end{abstract}

Keywords: information system, IT system, globalization, new technologies

JEL Classification: M10, M15, L20

\section{Introduction}

The Internet and the development of modern information technologies radically changed the way people function in the social and economic spheres. The enormous development of new forms of communication, such as mobile telephony, e-mails, transmission of different data, photos, films, without geographical limitation, radically reduced the time needed for the same activities as 20-30 years earlier. These changes also apply to business activities of 
enterprises. Today, talking to a contractor located on another continent is limited only to pulling the phone out of the pocket. With the help of a computer, tablet or phone, you can conduct video relations in real time (Broek \& Veenstra, 2018; Palvia et al., 2018; Vaujany et al., 2018; Talon-Ballestero et al., 2018; Khatri et al., 2018).

Nowadays, companies focus on the economy in a holistic way, not limited only to current activities. To meet the requirements of being competitive in the current global and constantly changing market, the companies expand their business activity to a virtual environment in the digital space. The space in which enterprises operate is constantly growing. For this reason, all the time entrepreneurs need to learn new business solutions and implement new solutions to maintain the desired market position (Jelonek, 2004; Townsend et al., 2018; Ravichandran, 2018).

\section{Methodology - Business Activity Under the Globalization}

In a modern society, the idea of globalization can be a key factor of the development on the global markets. Such phenomenon can connect economies of different countries in order to produce a global product (Salgovicova \& Klincekova, 2016). Many researchers deal with the definition of "globalization". Definition of Peter Drucker (1986) is following: "A fundamental change in the world economy, with changes cause structural shifts in international markets, product mix and commerce in the developed countries. The way how the production is made has been changed. "

Nowadays, globalization has become one of the most important determinants in management of the most of contemporary companies. Inclusion of the enterprises into the globalization process requires entirely new approach and attitudes with respect to relations with other people in different countries, with particular focus on economic, political, technological, cultural and other conditions. Very important role as the components of globalization fulfill management systems and integrated management systems implemented by enterprises, often supported by IT systems. Modern enterprises and organizations implement continuously different types of IT systems.

Globalization was at the beginning determined by modern information and communication technologies (ICT) and the Internet. It allowed, for instance, global trading in real time and had an impact at transport price reduction of cargo, people and money. Such new forms of exchange of information simplified business activities (Vanek et al., 2016; Venkatesh et al., 2018).

Rapid development of ICT technologies, allowed the liberalization of the world market and the opening of borders between countries. It can be observed that at the moment when the Internet network becomes so popular, we are faced with unprecedented acceleration. Both the pace of information transmission and also the amount of information available at any time of the day and in any latitude is impressive. Due to the expansion of the Internet, you can even name the world as a global library.

Internet technologies have caused the lives of many thousands of people today depend on their presence on the web. On the one hand, the Internet is a convenience for users, as it clearly decreases the time and costs of the company's activity. In addition, there are many people for whom new technologies "create" new workplaces. On the other hand, others may also lose it because of digital development.

Nowadays, socio-economic development is a function of technological progress. ICT infrastructure is a necessary condition, but not enough to form a creative information society. 
New information and communication technologies are still generating new opportunities, and the digitization and convergence of media cause easy access to an unlimited stream of information, ideas and views (Luczak, 2017; Kroh et al., 2018).

\section{Results - Information Needs and Measurement in Management and Accounting}

Measurement of economic phenomena is an important task of the management system. Measuring is one of the most important methods leading to analyzing the essence and character of economic events. By measuring, you learn about the surrounding economic reality. Its analysis allows information recipients to understand the dependencies that occur between individual elements of the system. In recent years, we can observe more and more dynamic changes in the environment of business entities. These changes cause an increase in the demand by managers of business units for the most up-to-date and current information on the economic and financial situation. Managers need quick access to the right information that is necessary for the efficient and effective management of an enterprise. The basis for the functioning of the organization is to have appropriate information that allows the implementation of management processes. Information is a type of enterprise resource that allows increasing economic knowledge in the organization regarding the individual company and its environment. Information is a basic element of business management and decision making process. Information in the management process is related to planning, organizing and coordinating, and allows decision-making at various levels of management (Kisielnicki, 2013).

The information system is an essential element of business management in theory and business practice. In order to meet the required management goals, an enterprise must have an information system that will provide appropriate information to decision-makers in a timely manner (Mesjasz-Lech, 2015).

The information system must be organized in order to ensure that internal users, both managers and employees, have access to individual data and information about the situation within the business unit, as well as changes occurring in the company's environment. The data flow in the information system does not occur only within the unit, but covers its environment, taking into account the suppliers, recipients and intermediaries.

The information system is a multi-level structure that allows its users to transform specific entry information into desired exit information using appropriate models and procedures. Due to the role and importance of the information generated, increasingly high demands are placed on modern information systems. The complexity of organizational relationships and making many decisions in a shorter and shorter time cause that the proper functioning enterprise on the global, more and more demanding market depends on having the proper information system (Nowicki \& Chomiak, 2011; Ding, 2018).

Determining the measurement used in economic sciences, including the management accounting system is necessary due to the fact that accounting can be defined as a system for measuring the effects of economic activity. Measurement is the process of objective assignment of numbers (indicators, measures) to properties of objects or events occurring in business units, by means of which they can be properly determined (measured) (Brzezin \& Knop, 2007). K. Ajdukiewicz describes measurement as the assignment of measured objects (or their features) to certain numbers as their measurement system (Ajdukiewicz, 1985). Theory of measurement was popular among many accounting theorists, such as Edwards \& Bell, Ijiri, Mattessich, Schweitzer, Jaruga, Dobija M., Burzymowa, Szychta, Dobija D., Brzezin \& Knop (Fijałkowska, 2012). 
The measurement is closely connected to the numbers, the graphic symbols, digits. Numbers are the most complex and abstract concepts. The number systems for a number of years have varied depending on the period of time and geographic location. In order to unify for the needs of various sciences, including accounting, a system of Arabic numerals was created (Brzezin \& Knop, 2007). Accounting, as applied science, is focused on a practical goal, i.e. measuring the flow and increase of value of property components, assigned to micro- and macroeconomic items for decision-making and settlement of social and economic efficiency.

Issues related to the measurement are very broad. There are two concepts connected with it: mathematical modelling and measuring. Mathematical modelling in accordance with W. Jakubiec and F. Malinowski (after: Brzezin \& Knop, 2006) consists in mapping the features of objects or events - with numbers, and the relationship between these features - relationships between numbers. Measuring, on the other hand, is an activity that leads to the determination of numbers modelling specific features of objects and events. Mathematical modelling leads to the creation of a measurement scale. The characteristic for which the scale is created is the size (also defined in a narrower sense as a property that can be presented qualitatively or quantified). The qualitative expression is the determination of properties, while the quantity must also be quantifiable, which means that the values of the quantity (the product of the number and the unit of measurement) should be determined (Brzezin \& Knop, 2006).

Measurement is an empirical process that leads to obtaining information about the value measured in the most convenient form due to the purpose it is to serve. The measurement consists in assigning measured objects and their features to numerical measures, in a homogeneous manner to objects and in a mutually unambiguous (isomorphic) way the features of these objects. Searching for a number assigned by an isomorphism or homomorphism, that meets these specified conditions, is a specific kind of measurement.

K. Ajdukiewicz distinguishes two types of proper measurement: direct measurement and indirect measurement (Ajdukiewicz, 1975). According to the concept of direct measurement, the examined values are determined by comparing them with a fixed unit of measurement based on a standard. These quantities are adequate with measuring units. They can also be multiples of measuring units (Wolk et al., 1984).

Indirect measurement assumes obtaining information about the economic events examined by finding measures of other quantities and then inference on the basis of established relationships between the found measures and the investigated events. The necessary condition that must be met is the occurrence of a general relationship between the measured quantities and the size that is the purpose of the measurement. Both, direct and indirect measurement, are more or less accurate reflection of the economic event being investigated by means of numbers. It is not always possible to compare the pattern to the measured element as closely as possible and to find the most precise indirect measure describing the object of the measurement (Pietrzak, 2011).

In the accounting system, where on the one hand there is historical-oriented financial accounting and, on the other hand, prospective management accounting, there is often a problem in imprecision and ambiguity in the measurement of economic events.

Measurement of events in the accounting system is based on information obtained from source documents on the basis of which accounting entries are made. The results of such measurement at the level of the analysed documents and their accounting records are quite unambiguous and it can be stated that this is a direct measurement. Another situation can occur when such a direct measurement of economic events is replaced by indirect measurement of complex phenomena, as can be seen in the case of measuring the financial 
result. Measurement of the financial result may give ambiguous information. Applying a different balance sheet policy, application of different accounting standards, legal regulations, may cause such a situation. The measurement of the financial result may not be an effective measure of the entity's economy due to the omission, during its determination, the fact of money's volatility, economic risk factors, and investment outlays. Long-term shaping of management effects is a better reflection of the individual's condition.

The indicators used in the management process of enterprises are often referred to as measures of economic categories expressing the expected and desired effect in the future. Measurement of economic phenomena in the management accounting system is to enable obtaining a set of data necessary in the management process. In order to enable conclusion in the scope of past effects, the measurement in the management accounting system has the following features (Gabrusewicz et al., 1998):

- there is a lack of legal regulations and the necessity to apply legally defined standards in the process of measuring phenomena,

- using different valuation rules,

- creation of many result variants, taking into account the variability of the measurement parameters,

- orientation on the significance, speed and quality of the measurement results obtained,

- freedom of presentation of measurement results.

For example, the measurement of the market value of capital determined in the ex-ante approach gives the base needed to determine the benefits for shareholders, resulting from the multiplication of the capital employed for the future determined for the future. There is a relativity and indirectness of measurement, which, however, undeniably fulfils the basic condition, that is, it reflects in a number (unit of measure) a specific economic phenomenon.

An objective assessment of economic quality phenomena is the value assessment, understood as the cost of producing a different quality. Various measures and indicators are used to measure and assess quantitative and qualitative phenomena.

The business activity ratio is an economic category that reflects events and management facts in appropriate units of measurement. Its essence comes down to measuring economic events occurring in the enterprise and its surroundings, and providing the necessary information to express this process.

The term measure is used when there are nominated numbers (natural, technical-economic, valuable measures) to measure quantitative phenomena and events and with nominated numbers, also referenced to some nominated basis and used to assess quantitative phenomena (e.g. profit in Euro per 1 employee). In this approach, the term indicator is traditionally used.

Indicators are used when there are relative numbers (very often percentages) used to assess quantitative and qualitative phenomena both in a static system (e.g. relative cost and profitability indicators) and in a dynamic system (different dynamics ratios and indexes with a constant or variable basis) (Twaróg, 2003).

The indicator is a structural form of economic information. The identifier of the economic indicator should have its formal characteristics - record. An element of the economic indicator identifier is the object it concerns. Such an object may be, for example, a company as a whole, a plant, a profit centre, a cost centre, and an investment centre. The objects may be processes implemented in the enterprise. The choice of the object depends primarily on the needs of financial analysis. The identifier is also the company. This means that the indicators should be assigned to the subject. The subject may be, for example, managers, analysts and functional services of the enterprise. 
The use of financial indicators in the enterprise's management system has been used for many years in the business practice of the enterprises. Indicators are usually of a synthetic nature, which is influenced by many events, which can be described with the help of other indicators of a lesser degree of generality.

For the proper use and analysis of such indicators, or even ratio systems, it is necessary nowadays to use appropriate IT tools, and hence appropriate IT systems supporting the management of a modern enterprise in a global and ever-changing environment.

\section{Discussion - IT Systems in Management}

An enterprise functioning on global markets must gather a lot of useful information to preserve profitability and competitive advantage. This information, due to the source of their formation, is divided into external and internal. External ones are those that are obtained from the company's environment; internal ones are created inside the enterprise. Information can also be divided due to the method and function of use as:

- decision - that support decision making in the company;

- control - which are helpful in control and supervision;

- coordination - which are related to the cooperation of market participants;

- planning - which are used to forecast and predict various scenarios in the company.

There are following features of information system in management of the enterprise: (Gołembska et al., 2013):

- reliability, defined as the possibility of meeting requirements,

- performance, as the relationship between the value spent on the system and resulting from the system,

- flexibility, which provides the two above features in business environment, and which means the ability to adapt to changing environment and development opportunities,

- openness, enabling interconnection of enterprises' information systems, which ensures the exchange of data between them, and allows for interrelation in the decision-making process - this is essential for supply chain,

- economic efficiency, which takes into account the cost aspect in relation to the fulfillment by the system of the above conditions.

Such features can be only provided by IT systems. Their extension of decision support systems enhances the integration of many decision areas, resulting in different business activities.

Modern companies can't run their business without information technologies. It is a result of numerous advantages of the modern IT solutions. Most important arguments for using IT systems are cost and time optimization (Ciszewski \& Nowakowski, 2016).

Nowadays IT systems are used in most enterprises. In these small ones, simple systems are more common, while in larger ones, where many economic processes occur and a large information base is transported, complex systems are most often used. They can more effectively support the running of the enterprise and the process of making decisions important for the company.

In practice, there is a tendency to create integrated systems. This concept is constantly and rapidly growing and developing. Gradually, all these basic management functions are covered by these systems in an enterprise: planning, organizing, motivating and controlling functions. The integrated system is built of various modules intended for data transformation processes supporting the functioning and operation of the unit. The integrated IT system supports all 
areas of the organization's activity: marketing, planning, procurement, technical preparation of production, distribution of finished products, sales of products, goods and services, running finance and accounting, HR management.

There are many integrated IT systems. An example of such a system is the MRP system. It was developed in the sixties. It supported the design of the production schedule. The operation of this system consisted in developing production tasks from top to bottom through individual stages, levels. On the basis of these schedules, production and purchasing orders were established. It involved the designed schedules with the production plans. At the beginning, the MRP's special task was to control material management, support planning and production scheduling, and the main objective of this system was to minimize the costs associated with storage, while maintaining a continuous production process.

The MRP system is considered not only as an IT management system, but also as a precise, accurate and comprehensive model of company's management.

The abbreviation MRP in the mid-sixties meant Material Requirements Planning. At the end of the eighties, this abbreviation changed its significance to the Manufacturing Resources Planning, and its was changed to MRP II.

The system of MRP II class supports management of inventory, finance and all company resources. The MRP II system does not differ from the MRP only in the title, but also that it has been supplemented with additional functions, like CRP (Capacity Requirements Planning), as well as components related to sales processes and supporting the decision making process in the strategic area of production management. The MRP II system, apart from materials related to production, includes auxiliary materials, human and financial resources, fixed assets, time and others.

MRP II class systems should implement, among others following functions:

- Business Planning - in this area the company's business plan is set;

- Sales and Operation Planning - it creates a sales and production plan that is related to the company's business plan. These plans affect all other operational plans in the company.

- Demand Management - deals with forecasting and sales planning as well as accepting consumer orders. It determines the future demand and its update.

- Master Production Scheduling - it is about balancing the production capacity, the supply of materials.

Other functions also include: Material Requirements Planning (MRP), material management support, warehouse registration, order management, production, capacity planning, management of workstations, financial planning and control of MRP II system performance efficiency (Banaszak et al., 2016).

Sales and marketing areas are also supported by integrated IT systems. In the nineties, CRM (Customer Relationship Management) system was created. It allows defining a set of techniques and tools that will support the management of relations with consumers using information technology. Currently, this system does not only close to the sales area, but also supports the tasks of marketing department, such as settlement and organization of advertising campaigns, management of marketing events and carrying out strategic analyzes (SWOT, etc.).

Research and development is the most expensive and at the same time the most important area in the company's activity. In the second half of the nineties, the PLM (Product Lifecycle Management) system was introduced, which had to support this area of the enterprise. The PLM system manages the creation and development of the product through all its stages. It supports the creation of a new product concept, the creation of a project, its production, and 
exploitation and finally the utilization of the product. This system is designed to integrate all participants in the process of creating and developing a new product, i.e. constructors, suppliers, recipients, technologists, etc. The PLM system has an impact on reducing the time of product design creation and implementation on the market, reducing the risk of introducing new products into the markets and improving their quality (Banaszak et al., 2016; Twarog, 2003).

MES systems are used in large enterprises with a mechanized and automated production line. These systems monitor the whole production process. They automatically collect data of this process, analyze the efficiency of the production system. The function of this system is also setting production schedules, assigning orders, controlling of production and analyzing the efficiency of the production process. The IT system supports the maintenance of production, so that the company is not exposed to unnecessary costs and losses.

Supply chain management is also supported by an integrated IT system. Without the suppliers, it is not possible to produce or even simply administrative activity of business unit. The supply chain includes: material suppliers, distributors, manufacturers, transport companies, service providers as well as warehouses and logistics centers. There are dependencies between all participants in the supply chain. The SCM system synchronizes the flow of materials between selected participants in the delivery process. This synchronization makes it easier for the company to adapt to a given market demand, especially on global markets.

Each integrated IT system is exposed to changes in the close and distant surroundings of the enterprise. The IT system, in order to be effective and properly functioning, should be adapted to the internal and external conditions of the company. The DEM (Dynamic Enterprise Modeler) system, which uses business models for various industries, makes it possible to increase the flexibility of IT systems. These models include, among others: the model of main processes, organizational processes and business functions (Nowicki \& Chomiak, 2011).

In every company, many documents are created, delivered and sent. DMS systems (Document Management System) are helpful in managing these documents and maintaining order in their storage. They deal with indexing documents, storing them, in such a way as to be easily accessible to them. DMS systems integrate and cooperate with other IT systems used in the enterprise.

The creation of the ERP (Enterprise Resource Planning) system is the next stage in the development of all production control and planning systems. The ERP system is defined as a group of interconnected solutions (IT methods) supporting the activity of the whole enterprise. Such systems can also be implemented in non-profit organizations and public bodies. Starting from the original form of the company management support system - IC (Inventory Control) - by moving to MRP systems, later MRP II, developed; comprehensive ERP systems were created, which were increasingly combined with the SCM and CRM system (created in about 2000).

ERP systems achieve their goals through analysis, recording, control and improvement of their functioning. In addition to bookkeeping, they started to deal with management accounting, which is part of controlling. The functions, that ERP performs, help in achieving a company's competitive advantage in the market. The entire system is available to users in selected or in all departments of the company. The scope of the system's functionality depends on the decisions made by the managers. Instead of standard systems, a company can purchase a system adapted to the profile, branch of industry of a given company, that meets all its information needs. 
Systems of this class are the most developed management support systems that combine the features of transactional systems, management information systems and advisory systems (Drury, 2012; Matusova, 2016).

The most advanced are the ERP II systems, that are, the development of ERP systems with value-added applications for customers and stakeholders through the optimization and sharing of financial and operational processes.

Developing ERP II systems is a natural response to dynamically changing market needs and rapid technological progress. The ERP II system is characterized by enhanced functionality in core domain areas, providing enterprise employees with access to the system base via the Internet, and integrating ERP systems with market partners, both suppliers and recipients.

Integrated IT systems of ERP class more often support large enterprises running their business on global markets, as they have more departments in which a huge amount of data is processed.

\section{Conclusion}

The use of IT systems in enterprise management enables fast data exchange between individual areas of the company as well as between enterprises being business partners. However, often the use of the basic ERP IT system as the only IT tool that supervises all processes occurring in the enterprise is often insufficient. It is caused by the complexity of management processes and the specificity of a given enterprise. The need for support the processes implemented in the enterprise with additional IT tools and the increase of process specialization causes, that the need for dedicated systems supporting ERP systems is still growing.

Global enterprises have often a problem in integration IT systems inside the organization or in their supply chains. This may result from the use of various types and formats of information, various data drives, as well as from the use of various IT systems by users. When each participant of the supply chain realizes the benefits it can have from it, then he/she often leads to full integration of the supply chain. This is not an easy process, because such integration process forces the introduction of a number of organizational, structural and controlling changes, basis of data and documentation flows as well as changes in the functioning of the IT system used by the company.

\section{References}

Ajdukiewicz, K. (1975). Logika Pragmatyczna, PWN, Warszawa.

Ajdukiewicz, K. (1985). Język i Poznanie, t. 2, PWN, Warszawa.

Banaszak, Z., Kłos, S. \& Mleczko, J. (2016). Zintegrowane Systemy Zarządzania. Warszawa: Polskie Wydawnictwo Ekonomiczne.

Broek, T.V. \& Veenstra, A.F. (2018). Governance of Big Data Collaborations: How to Balance Regulatory Compliance and Disruptive Innovation. Technological Forecasting and Social Change, 129, 330-338.

Brzezin, W. \& Knop, J. (2006). Przyczynek do Dyskusji nad Teoria Pomiaru w Rachunkowości, Zeszyty Teoretyczne Rachunkowości, 32(88), 32.

Brzezin, W. \& Knop, J. (2007). Teoria Pomiaru w Rachunkowości a Systemy Cyfr. Poznan, Poland: Wydawnictwo AE w Poznaniu, 47.

Ciszewski, T. \& Nowakowski, W. (2016). Interoparability of IT Systems in the International Railways, Proceedings of 16th International Scientific Conference Globalization and Its Socio-Economic Consequences, Rajecke Teplice, Slovakia, pp. 312-320 
Ding, Y. (2018). Modelling Continued Use of Information Systems From a Forward-Looking Perspective: Antecedents and Consequences of Hope and Anticipated Regret. Information \& Management, 55(4), 461471.

Drury, C. (2012). Management and Cost Accounting. Hampshire: Cengage Learning EMEA.

Fijałkowska, J. (2012). Pomiar w Rachunkowości. Łódź, Poland: Wydawnictwo SAN.

Gabrusewicz, W., Kamela-Sowinska, A. \& Poetschke, H. (1998). Rachunkowość Zarządcza, PWE, Warszawa.

Gołembska, E., Sławinska, M. \& Szymczak, M. (2013). Kompendium Wiedzy o Logistyce. Warszawa: Wydawnictwo Naukowe PWN.

Jelonek, D. (2004). Wybrane Źródta Konkurencyjnej Przewagi Przedsiębiorstwa w Przestrzeni Internetowej, Polskie Stowarzyszenie Zarzadzania Wiedza. Seria Studia i Materiały, 3, 19-26.

Khatri, V., Samuel, B.M. \& Dennis, A.R. (2018). System 1 and System 2 Cognition in the Decision to Adopt and Use a New Technology. Information \& Management, 55(6), 709-724.

Kisielnicki, J. (2013). Systemy Informatyczne Zarzadzania. Warszawa: Placet.

Kroh, J., Luetjen, H., Globocnik, D. \& Schultz, C. (2018). Use and Efficacy of Information Technology in Innovation Processes: The Specific Role of Servitization. Journal of Product Innovation Management, 35(5).

Łuczak, M. (2017). Rola Nowych Technologii w Ewolucji Globalizacji. Katowice, Poland: Zeszyty Naukowe Uniwersytetu Ekonomicznego w Katowicach.

Matusova, D. (2016). Software Support for Facility Management and Versatility in Worldwide Action, Proceedings of 16th International Scientific Conference Globalization and Its Socio-Economic Consequences, Rajecke Teplice, Slovakia, 1322-1329.

Mesjasz-Lech, A. (2015). Effects of IT use in Improving Customer Service Logistic Processes. Procedia Computer Science, 65, 961-970.

Nowicki, A. \& Chomiak, I. (2011). Analiza i Modelowanie Systemów Informacyjnych. Wrocław: Wydawnictwo Uniwersytetu Ekonomicznego.

Palvia, P., Baqir, N. \& Nemati, H. (2018). ICT for Socio-Economic Development: A Citizens' Perspective. Information \& Management, 55(2), 160-176.

Drucker, F.P. \& Noel, L.J. (1986). Innovation and Entrepreneurship: Practices and Principles. The Journal of Continuing Higher Education, 34(1), 22-23.

Pietrzak, P. (2011). Wybrane Aspekty Pomiaru Zjawisk Ekonomicznych w Rachunkowości Finansowej i Rachunkowości Zarządczej, Zeszyty Naukowe Uniwersytetu Szczecińskiego. Finanse, Rynki Finansowe, Ubezpieczenia, 32(625), 187-188.

Ravichandran, T. (2018). Exploring the Relationships Between IT Competence, Innovation Capacity and Organizational Agility. The Journal of Strategic Information Systems, 27(1), 22-42.

Salgovicova, J. \& Klincekova, S. (2016). Globalization and its Impact on Values of Information Society, Proceedings of 16th International Scientific Conference Globalization and Its Socio-Economic Consequences, Rajecke Teplice, Slovakia, 1940-1945.

Talon-Ballestero, P. et al. (2018). Using Big Data From Customer Relationship Management Information Systems to Determine the Client Profile in the Hotel Sector. Tourism Management, 68, 187-197.

Townsend, M., Quoc, T.L., Kapoor, G., Hu, H., Zhou, W. \& Piramuthu, S. (2018). Real-Time Business Data Acquisition: How Frequent is Frequent Enough? Information \& Management, 55(4), 422-429.

Twarog (2003). Mierniki i Wskaźniki Logistyczne. Instytut Logistyki i Magazynowania, Poznan, Poland.

Vanek, J., Ocenasek, V., Stoces, M. and Masner, J. (2016). Adoption of Modern ICT in Regional Perspective Situation in the Czech Republic. Proceedings of 16th International Scientific Conference Globalization and Its Socio-Economic Consequences, Rajecke Teplice, Slovakia, 2291-2298.

Vaujany, F.D., Fomin, V.V., Haefliger, S. \& Lyytinen, K. (2018). Rules, Practices, and Information Technology: A Trifecta of Organizational Regulation. Information Systems Research, 29(3), 755-773.

Venkatesh, V., Rai, A. \& Maruping, L.M. (2018). Information Systems Projects and Individual Developer Outcomes: Role of Project Managers and Process Control. Information Systems Research, 29(1), 127-148.

Wolk, H.I., Francis, J.R. \& Tearney, M.G. (1984). Accounting Theory. A Conceptual and Institutional Approach, PWS-KENT Publishing Company, Belmont. 